Article

\title{
Improving the Performance of Horseradish Peroxidase by Site-Directed Mutagenesis
}

\author{
Diana Humer and Oliver Spadiut * \\ TU Wien, Institute of Chemical, Environmental and Bioscience Engineering, \\ Research Area Biochemical Engineering, Gumpendorfer Straße 1a, 1060 Vienna, Austria; \\ diana.humer@tuwien.ac.at \\ * Correspondence: oliver.spadiut@tuwien.ac.at
}

Received: 23 January 2019; Accepted: 16 February 2019; Published: 20 February 2019

check for updates

\begin{abstract}
Horseradish peroxidase (HRP) is an intensely studied enzyme with a wide range of commercial applications. Traditionally, HRP is extracted from plant; however, recombinant HRP (rHRP) production is a promising alternative. Here, non-glycosylated rHRP was produced in Escherichia coli as a DsbA fusion protein including a Dsb signal sequence for translocation to the periplasm and a His tag for purification. The missing $\mathrm{N}$-glycosylation results in reduced catalytic activity and thermal stability, therefore enzyme engineering was used to improve these characteristics. The amino acids at four $\mathrm{N}$-glycosylation sites, namely N13, N57, N255 and N268, were mutated by site-directed mutagenesis and combined to double, triple and quadruple enzyme variants. Subsequently, the rHRP fusion proteins were purified by immobilized metal affinity chromatography (IMAC) and biochemically characterized. We found that the quadruple mutant rHRP N13D/N57S/N255D/N268D showed 2-fold higher thermostability and 8-fold increased catalytic activity with 2,2'-azino-bis(3-ethylbenzothiazoline-6-sulphonic acid) (ABTS) as reducing substrate when compared to the non-mutated rHRP benchmark enzyme.
\end{abstract}

Keywords: E. coli; recombinant horseradish peroxidase; site-directed mutagenesis; periplasm; glycosylation sites

\section{Introduction}

The enzyme horseradish peroxidase (EC 1.11.1.7) is a heme-containing oxidoreductase used in both research and diagnostics for a wide range of applications (e.g., immunoassays, diagnostic kits, probe-based assay techniques as ELISA, EMSA, Western blotting and Southern blotting, waste water treatment and as a reagent in organic synthesis [1-7]. This 308 amino acid metalloenzyme incorporates two calcium atoms and four disulphide bridges [8,9]. In the plant, HRP also contains a hydrophobic 30 amino acid $\mathrm{N}$-terminal leader sequence and a 15 amino acid C-terminal extension [10]. The C-terminal sequence is a sorting signal responsible for secretion to the vacuole [11] and the N-terminal sequence directs the enzyme to the endoplasmatic reticulum (ER) for post translational modifications, namely heme and calcium incorporation, disulphide bond formation and $\mathrm{N}$-glycosylation [12]. The asparagine-linked glycans represent about a fifth of the $44 \mathrm{kDa}$ plant holoenzyme. HRP possesses nine potential glycosylation sites and the pattern as well as the occupation of these sites is heterogeneous between HRP variants $[13,14]$. At least 28 different native HRP isoforms have been described so far [15] out of which HRP C is the most abundant and therefore the most studied one [9].

The commercially available HRP is extracted from Armoracia rusticana roots. However, only seasonal availability and long cultivation times paired with low yields make the classical production process undesirable. Moreover, the content of single isoenzymes is often very low and downstream processing is tedious. As a consequence, there is a need for a uniform enzyme preparation with defined characteristics and recombinant protein production would mitigate this issue. Many studies have 
addressed Saccharomyces cerevisiae or Pichia pastoris as host organisms for rHRP production because yeasts are easy to cultivate and commonly used for glycosylated and disulphide bond containing proteins. Alas, in yeast hyper-glycosylation occurs and the downstream process is cumbersome. Prokaryotes on the other hand lack the organelles necessary for glycosylation, namely ER and Golgi apparatus. In addition, the reducing environment in the cytoplasm of bacteria impedes the formation of disulphide bridges. Hence, recombinant glycoproteins with disulphide bridges are usually not produced in bacteria. However, E. coli is a very convenient host organism because of its cheap and easy cultivation at high cell densities. Moreover, there are no obstacles due to hyper-glycosylation as it is the case in yeast. This substantially facilitates downstream processing and allows application of the product for therapeutic use. It has also been shown that glycosylation is not essential for HRP activity or folding [16] although enzyme activity and thermal stability are considerably reduced when compared to the native enzyme $[15,17]$. Many studies have already been performed with the goal to enhance the general stability and activity properties of rHRP (Table 1).

Table 1. List of rHRP mutations that improve enzyme performance, listed by authors.

\begin{tabular}{|c|c|c|}
\hline Mutation & Effect & Reference \\
\hline N13D & $\begin{array}{l}\text { Increased stability towards } \mathrm{H}_{2} \mathrm{O}_{2} \\
\text { Increased thermal stability }\end{array}$ & $\begin{array}{l}\text { Asad et al. [18] } \\
\text { Capone et al. [19] }\end{array}$ \\
\hline N268D & $\begin{array}{c}\text { Increased stability towards } \mathrm{H}_{2} \mathrm{O}_{2} \\
\text { Increased thermal stability } \\
\text { Increased substrate specificity for } \\
\text { phenol/4-aminoantipyrine } \\
\text { Increased activity with phenol/4-aminoantipyrine }\end{array}$ & $\begin{array}{l}\text { Asad et al. [18] } \\
\text { Asad et al. [20] } \\
\text { Capone et al. [19] }\end{array}$ \\
\hline N268G & $\begin{array}{l}\text { Increased stability towards } \mathrm{H}_{2} \mathrm{O}_{2} \\
\text { Increased thermal stability } \\
\text { Increased substrate specificity for } \\
\text { phenol/4-aminoantipyrine }\end{array}$ & Asad et al. [20] \\
\hline N57S & $\begin{array}{l}\text { Increased activity with } \mathrm{ABTS} \\
\text { Increased activity with } \mathrm{H}_{2} \mathrm{O}_{2} \\
\text { Increased thermal stability }\end{array}$ & Capone et al. [19] \\
\hline N186D & Increased activity with ABTS & Capone et al. [19] \\
\hline N198D & Increased substrate specificity for ABTS & Capone et al. [19] \\
\hline N255D & $\begin{array}{c}\text { Better folding in E. coli } \\
\text { Increased activity with ABTS } \\
\text { Increased activity with } \mathrm{H}_{2} \mathrm{O}_{2}\end{array}$ & $\begin{array}{l}\text { Lin et al. [21] } \\
\text { Capone et al. [19] }\end{array}$ \\
\hline N158D & Increased activity with $\mathrm{H}_{2} \mathrm{O}_{2}$ & Capone et al. [19] \\
\hline $\mathrm{K} 232 \mathrm{~N}$ & $\begin{array}{l}\text { Increased activity with ABTS } \\
\text { Increased thermal stability } \\
\text { Increased solvent stability } \\
\text { Increased stability towards } \mathrm{H}_{2} \mathrm{O}_{2}\end{array}$ & $\begin{array}{l}\text { Ryan et al. [22] } \\
\text { Ryan et al. [23] }\end{array}$ \\
\hline $\mathrm{K} 232 \mathrm{~F}$ & $\begin{array}{l}\text { Increased activity with ABTS } \\
\text { Increased thermal stability } \\
\text { Increased solvent stability }\end{array}$ & Ryan et al. [22] \\
\hline E238Q & Increased substrate specificity for ABTS & Ryan et al. [22] \\
\hline K241N & Increased activity with ABTS & Ryan et al. [22] \\
\hline K241E & $\begin{array}{c}\text { Increased substrate specificity for ABTS } \\
\text { Increased activity with ABTS }\end{array}$ & Ryan et al. [22] \\
\hline K241A & $\begin{array}{c}\text { Increased activity with ABTS } \\
\text { Increased stability towards } \mathrm{H}_{2} \mathrm{O}_{2}\end{array}$ & $\begin{array}{l}\text { Ryan et al. [22] } \\
\text { Ryan et al. [23] }\end{array}$ \\
\hline
\end{tabular}


Table 1. Cont.

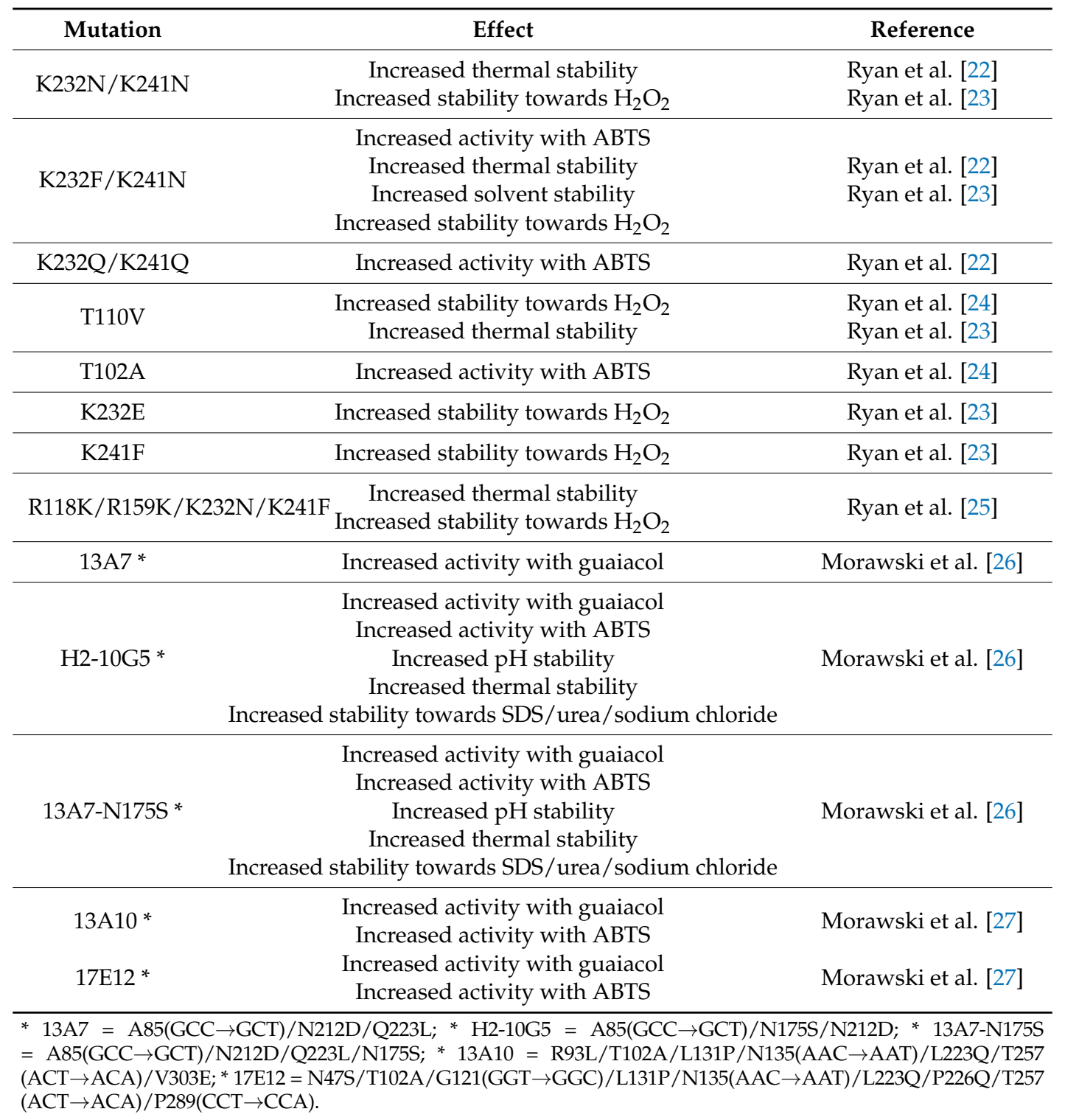

Lin et al. [21] identified a N255D mutant by random mutagenesis with 14 -fold higher activity than the non-mutated benchmark enzyme but they concluded that this increase was due to better folding of the enzyme rather than improved catalytic performance. Directed evolution was used to identify mutants 13A10 and 17E12 (for mutant descriptions see Table 1, Footnotes) in P. pastoris, which were associated with increased specific activity with ABTS (5.4-fold and 2.8-fold) and guaiacol (2.4-fold and 1.2-fold) as substrates. The thermostability of 13A10 was comparable to the non-mutated benchmark enzyme but it was remarkably decreased in 17E12 mutants [27]. Variant 13A10 was used as starting point for successive rounds of directed evolution and gave rise to 13A7, H2-10G5 and 13A7-N175S (for mutant descriptions see Table 1, Footnotes). These variants were found to be more stable towards $\mathrm{pH}$, temperature, SDS, urea and sodium chloride but enzyme activity was not further improved [26]. Ryan et al. [23] intensely studied the influence of site-directed mutations on hydrogen peroxide tolerance. They identified T110V, K232N and K241F, which were 25-, 18- and 12-fold more resistant towards hydrogen peroxide than the non-mutated benchmark enzyme. These variants also showed increased tolerance to heat and solvents. In addition, $\mathrm{K} 232 \mathrm{~N}$ as well as $\mathrm{K} 241 \mathrm{~F}$ displayed higher turnover numbers $\left(\mathrm{k}_{\mathrm{cat}}\right)$ with ABTS as reducing substrate [22]. Asad et al. [18] changed the amino acids present at two N-glycosylation sites of rHRP by site-directed mutagenesis. They described variants N13D and 
N268D, which showed increased catalytic efficiency with phenol/4-aminoantipyrine and were both more stable in terms of hydrogen peroxide and heat tolerance. A follow-up study identified N268G, which showed 18-fold higher resistance towards hydrogen peroxide and 2.5-fold higher thermal stability [20]. Capone et al. [19] performed a profound investigation of $\mathrm{N}$-glycosylation mutants in P. pastoris, where asparagines at eight sites were replaced by aspartic acid, serine or glutamine. They showed that the positive influence of N13D and N268D on thermal stability is also valid for expression in yeast and that the variant identified by Lin et al. [21] was apparently slightly beneficial in terms of catalytic activity. Interestingly, a variant with mutations at all eight $N$-glycosylation sites showed substantially decreased activity and thermal stability.

At the moment, HRP is not used for in vivo medical applications, because the plant glycosylation pattern differs significantly from human glycoforms and therefore has immunogenic potential [28]. This can be circumvented by reducing the glycosylation pattern to mannose-type glycans, which can be achieved by adding an ER retention sequence. Unfortunately, these glycans lead to rapid clearance from circulation in humans [28]. Nevertheless, a combination of HRP and paracetamol or the plant hormone indole-3-acetic acid (IAA) was found to be medically active in targeted cancer treatment [29,30]. Although this cytotoxic effect has been known since the nineties [31,32], up to now, $\mathrm{HRP}$ is not considered suitable for therapeutic use. For this application, a recombinantly produced single isoform free of glycosylation with sufficient stability and activity would be desirable. In this study, we investigated the N-glycosylation mutants N13D, N57S, N255D, N268D and combinations thereof for thermal stability and catalytic efficiency with the substrate ABTS for rHRP expressed in E. coli. Soluble rHRP was preferred for mutant screenings because refolding of rHRP from E. coli inclusion bodies is a complex and cumbersome procedure which still has to be optimized. Therefore, we chose an expression system that leads to translocation of rHRP into the periplasm. The aim of this work was to improve the traits of non-glycosylated rHRP towards higher stability and catalytic efficiency to increase suitability for medical applications. Indeed, a promising rHRP N-glycosylation mutant was identified and biochemically characterized.

\section{Results and Discussion}

\subsection{Protein Production}

Recombinant HRP variants were produced and then translocated to the periplasm by the DsbA signal sequence. Soluble proteins were isolated from the periplasm and rHRP was purified to gain active, correctly folded enzyme. The imidazole concentration in the IMAC binding buffer was at the upper limit given by the column manufacturer (GE Healthcare, Chicago, IL, USA) to avoid unspecific interactions between $E$. coli host cell proteins and the stationary IMAC phase. Nevertheless, several impurities were visible on the SDS PAGE of the IMAC eluate (data not shown). Therefore, rHRP concentrations were calculated using an SDS-PAGE HRP standard curve with known concentrations (Figure S1). The peak area of rHRP was determined using Fiji Image Analysis Software (https: / / fiji.sc) [33] and the protein content was calculated using the slope of the linear regression line of known rHRP concentrations. This led to final enzyme titres of $0.05-0.09 \mathrm{mg}^{\mathrm{rHRP} \mathrm{g}}{ }^{-1} \mathrm{DCW}$. The final rHRP product yield was between $0.04-0.08 \mathrm{~g} \mathrm{~L}^{-1}$ and is similar to reported values from Gundinger et al. [17] for soluble rHRP in pET39b $\left(0.048 \mathrm{~g} \mathrm{~L}^{-1}\right)$.

\subsection{Biochemical Characterization}

\subsubsection{Biochemical Characterization of Benchmark rHRP and Seven rHRP Mutants}

\subsubsection{Enzyme Kinetics}

Plant HRP VI-A (Sigma-Aldrich, St. Louis, MO, USA), non-mutated benchmark rHRP and the seven rHRP variants N13D, N57S, N255D, N268D, N57S/N268D, N57S/N255D/N268D and N13D/N57S/N255D/N268D were analysed for steady-state kinetics with ABTS as reducing substrate. 
The kinetic constants are presented in Table 2. N13D and N255D showed less catalytic efficiency $\left(\mathrm{K}_{\mathrm{cat}} / \mathrm{K}_{\mathrm{m}}\right)$ than the benchmark enzyme and for N13D this is in accordance with Capone et al. [19]. For N255D on the other hand, Capone et al. [19] observed almost the same catalytic activity compared to the benchmark enzyme (1.1-fold increase). N268D had a 2-fold increased turnover number $\left(\mathrm{k}_{\mathrm{cat}}\right)$ when compared to the non-mutated rHRP and the same trend was shown by Asad et al. [20], where a 2.6-fold enhanced $\mathrm{k}_{\text {cat }}$ with phenol/4-aminoantipyrine was reported. The slightly enhanced catalytic efficiency of N57S, when compared to the benchmark rHRP (1.2-fold), is in accordance with Capone et al. [19] (1.4-fold). The triple mutant N57S/N255D/N268D reached a 3.2-fold higher turnover number than the benchmark rHRP and with a 10-fold increase, N13D/N57S/N255D/N268D showed the highest fold change of $k_{\text {cat }}$ when compared to the benchmark rHRP. However, only N57S and N13D/N57S/N255D/N268D had an increased catalytic efficiency when compared to the non-mutated rHRP (1.2-fold and 2-fold, respectively). In general, the results were greatly affected by the unusually high Michaelis Menten constants $\left(\mathrm{K}_{\mathrm{m}}\right)$ and the considerable standard deviations (see Section 2.2.2).

Table 2. Kinetic characteristics of plant HRP, rHRP and seven rHRP variants with ABTS as reducing substrate measured in $50 \mathrm{mM}$ BisTris $/ \mathrm{HCl}$ pH 7, 7\% glycerol, $100 \mathrm{mM} \mathrm{NaCl}$.

\begin{tabular}{ccccc}
\hline HRP variant & $\mathbf{K}_{\mathbf{m}}[\mathbf{m M}]$ & $\mathbf{V}_{\mathbf{m a x}}\left[\mathbf{m o l}^{-\mathbf{1}} \mathbf{L}^{-\mathbf{1}} \times \mathbf{s}\right]$ & $\mathbf{K}_{\mathbf{c a t}}\left[\mathbf{s}^{-\mathbf{1}}\right]$ & $\mathbf{K}_{\mathbf{c a t}} / \mathbf{K}_{\mathbf{m}}\left[\mathbf{m M}^{-\mathbf{1}} \mathbf{s}^{-\mathbf{1}}\right]$ \\
\hline Benchmark rHRP & $2.82 \pm 1.52$ & $1.7 \times 10^{-6} \pm 4.3 \times 10^{-7}$ & $1.52 \pm 0.38$ & $0.54 \pm 0.32$ \\
N13D & $3.29 \pm 0.33$ & $8.8 \times 10^{-7} \pm 4.0 \times 10^{-8}$ & $1.04 \pm 0.05$ & $0.32 \pm 0.04$ \\
N57S & $3.22 \pm 0.59$ & $2.7 \times 10^{-6} \pm 2.6 \times 10^{-7}$ & $2.10 \pm 0.19$ & $0.64 \pm 0.13$ \\
N255D & $4.37 \pm 0.86$ & $8.9 \times 10^{-7} \pm 1.0 \times 10^{-7}$ & $1.10 \pm 0.12$ & $0.24 \pm 0.05$ \\
N268D & $7.85 \pm 4.98$ & $2.4 \times 10^{-6} \pm 1.0 \times 10^{-6}$ & $3.00 \pm 1.25$ & $0.38 \pm 0.29$ \\
N57S/N268D & $4.18 \pm 3.55$ & $1.0 \times 10^{-6} \pm 3.9 \times 10^{-7}$ & $1.50 \pm 0.58$ & $0.36 \pm 0.34$ \\
N57S/N255D/N268D & $9.52 \pm 6.89$ & $4.0 \times 10^{-6} \pm 2.0 \times 10^{-6}$ & $4.81 \pm 2.37$ & $0.51 \pm 0.44$ \\
N13D/N57S/N255D/N268D & $13.6 \pm 6.63$ & $1.7 \times 10^{-5} \pm 5.6 \times 10^{-6}$ & $15.1 \pm 5.00$ & $1.11 \pm 0.65$ \\
HRP Type VI-A & $9.46 \pm 5.18$ & $5.7 \times 10^{-3} \pm 1.8 \times 10^{-3}$ & $271 \pm 87.4$ & $28.7 \pm 18.3$ \\
\hline
\end{tabular}

\subsubsection{Thermal Stability}

The thermal stability of plant HRP VI-A, non-mutated benchmark rHRP and the seven rHRP variants was determined at $60^{\circ} \mathrm{C}$ (Table 3). N13D and N268D were found to enhance stability towards heat, which is in accordance with Asad et al. [18] and Capone et al. [19]. However, Capone et al. [19] also reported a positive effect of N57S, which could not be confirmed. Variant N255D seemed to have no effect on thermal stability. The double mutant N57S/N268D was similar to the rHRP benchmark enzyme concerning temperature susceptibility, so apparently the effect of the mutations is not additive. N268D had the highest benefit and was 3.6-fold more stable than the non-mutated rHRP, whereas the quadruple mutant N13D/N57S/N255D/N268D was 2.4-fold enhanced. Although N268D was the most thermostable variant, the quadruple mutant was chosen for further investigations, as this variant showed promising results for both catalytic activity and thermal stability.

Table 3. Half-life of plant HRP, rHRP and seven $\mathrm{rHRP}$ variants at $60^{\circ} \mathrm{C}$ in $50 \mathrm{mM}$ BisTris $/ \mathrm{HCl} \mathrm{pH} 7$, $7 \%$ glycerol, $100 \mathrm{mM} \mathrm{NaCl}$.

\begin{tabular}{cc}
\hline HRP Variant & $\boldsymbol{t}_{\mathbf{1 / 2}}$ at $\mathbf{6 0}{ }^{\circ} \mathbf{C}$ \\
\hline Benchmark rHRP & $2 \min 39 \mathrm{~s} \pm 16 \mathrm{~s}$ \\
N13D & $3 \min 53 \mathrm{~s} \pm 16 \mathrm{~s}$ \\
N57S & $2 \min 46 \mathrm{~s} \pm 14 \mathrm{~s}$ \\
N255D & $2 \min 48 \mathrm{~s} \pm 9 \mathrm{~s}$ \\
N268D & $9 \min 32 \mathrm{~s} \pm 2 \min 18 \mathrm{~s}$ \\
N57S/N268D & $2 \min 14 \mathrm{~s} \pm 56 \mathrm{~s}$ \\
N57S/N255D/N268D & $5 \min 51 \mathrm{~s} \pm 18 \mathrm{~s}$ \\
N13D/N57S/N255D/N268D & $6 \min 19 \mathrm{~s} \pm 12 \mathrm{~s}$ \\
HRP Type VI-A & $117 \min \pm 9 \min 55 \mathrm{~s}$ \\
\hline \multicolumn{2}{c}{$\boldsymbol{t}_{\mathbf{1 / 2}}=$ half life. }
\end{tabular}




\subsubsection{Catalytic Activity of Plant HRP under Different Conditions}

Interestingly, all obtained Michaelis Menten constants (Table 2) were much higher than previously reported for soluble rHRP variants [17] and this was also the case for commercially available plant HRP $[17,34,35]$. The substantial variability of the obtained Michaelis Menten constants may be a direct result of the high $\mathrm{K}_{\mathrm{m}}$ values we observed due to fast reactions and high slopes, as variability increases with reaction velocity (see Table 2). We assumed that the measurement buffer was influencing the results of the kinetic measurements, as this was the only apparent difference to the previous procedure from Gundinger et al. [17]. Therefore, the catalytic activity of plant HRP was determined in both buffers: $50 \mathrm{mM}$ BisTris/ $\mathrm{HCl} \mathrm{pH}$ 7, 7\% glycerol, $100 \mathrm{mM} \mathrm{NaCl}$ and $50 \mathrm{mM} \mathrm{KH}_{2} \mathrm{PO}_{4} \mathrm{pH} 6$ (Table 4). The results indicated that the high Michaelis Menten constants, as well as the high standard deviations, are indeed buffer dependent. The $\mathrm{K}_{\mathrm{m}}$ value was 6-fold higher in $50 \mathrm{mM}$ BisTris $/ \mathrm{HCl} \mathrm{pH} \mathrm{7,} \mathrm{7 \%} \mathrm{glycerol,} 100 \mathrm{mM}$ $\mathrm{NaCl}$ buffer when compared to $50 \mathrm{mM} \mathrm{KH}_{2} \mathrm{PO}_{4} \mathrm{pH}$ 6. As a consequence, the catalytic efficiency was 9-fold enhanced when the measurements were performed in potassium phosphate buffer. The kinetic parameters observed with $50 \mathrm{mM} \mathrm{KH}_{2} \mathrm{PO}_{4} \mathrm{pH} 6$ are in accordance with Gundinger et al. [17], as they reported a $\mathrm{K}_{\mathrm{m}}$-value of $1.75 \mathrm{mM}$ and a $\mathrm{V}_{\text {max }}$-value of $567 \mathrm{U} \mathrm{mg}^{-1}$.

Table 4. Comparison of kinetic characteristics measured with plant HRP Type VI-A in two different buffers.

\begin{tabular}{|c|c|c|c|c|}
\hline Buffer & $\mathrm{K}_{\mathrm{m}}[\mathrm{mM}]$ & $\mathrm{V}_{\max }\left[\mathrm{mol}^{-1} \mathrm{~L}^{-1} \times \mathrm{s}\right]$ & $K_{\text {cat }}\left[s^{-1}\right]$ & $\mathrm{K}_{\mathrm{cat}} / \mathrm{K}_{\mathrm{m}}\left[\mathrm{mM}^{-1} \mathrm{~s}^{-1}\right]$ \\
\hline Buffer 1 & $9.46 \pm 5.18$ & $5.7 \times 10^{-3} \pm 1.8 \times 10^{-3}$ & $272 \pm 87.4$ & $28.7 \pm 18.3$ \\
\hline Buffer 2 & $1.51 \pm 0.15$ & $7.9 \times 10^{-3} \pm 6.3 \times 10^{-4}$ & $378 \pm 30.0$ & $251 \pm 32.2$ \\
\hline
\end{tabular}

However, at this point it was still unclear whether these results were obtained because of the buffer substance, the $\mathrm{pH}$ change or the additives in the BisTris buffer. Therefore, the specific activity of plant HRP with ABTS as reducing substrate was examined under different conditions (Figure 1). Apparently, the additives glycerol and sodium chloride have a negative influence, as the specific activity was 2-fold enhanced when they were omitted. The two buffers $50 \mathrm{mM} \mathrm{KH}_{2} \mathrm{PO}_{4} \mathrm{pH} 7$ and $50 \mathrm{mM}$ BisTris/ $\mathrm{HCl} \mathrm{pH} 7$ led to comparable results. The catalytic activity at $\mathrm{pH} 5$ was 3 -fold enhanced when compared to $\mathrm{pH} 7$ when the measurements were conducted in potassium phosphate buffer. Based on these results, we decided to use $50 \mathrm{mM} \mathrm{KH}_{2} \mathrm{PO}_{4} \mathrm{pH} 5$ for all consecutive measurements (Section 2.2.3).

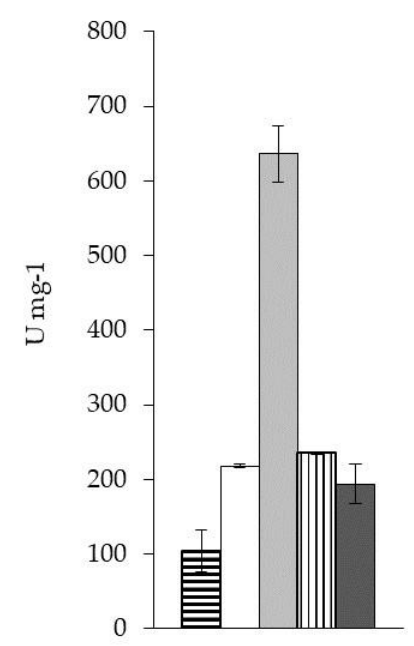

Figure 1. Specific activity of plant HRP Type VI-A with ABTS under various conditions. Five different buffers were used to measure the catalytic activity of plant HRP with $5 \mathrm{mM}$ ABTS and $1 \mathrm{mM}$ hydrogen peroxide. Horizontal stripes: $50 \mathrm{mM}$ BisTris/ $\mathrm{HCl} \mathrm{pH} \mathrm{7,7 \%} \mathrm{glycerol,} 100 \mathrm{mM} \mathrm{NaCl}$; white: $50 \mathrm{mM}$ BisTris/ $\mathrm{HCl} \mathrm{pH}$ 7; light grey: $50 \mathrm{mM} \mathrm{KH}_{2} \mathrm{PO}_{4} \mathrm{pH}$ 5; vertical stripes: $50 \mathrm{mM} \mathrm{KH}_{2} \mathrm{PO}_{4} \mathrm{pH}$ 6.5; dark grey: $50 \mathrm{mM} \mathrm{KH}_{2} \mathrm{PO}_{4} \mathrm{pH} 7$. 
2.2.3. Optimized Biochemical Characterization of Benchmark rHRP and Mutant N13D/N57S/N255D/N268D

The first investigation (Section 2.2.1) showed that the quadruple mutant N13D/N57S/N255D/N268D was the most promising variant when compared to the non-mutated benchmark rHRP (Tables 2 and 3). Therefore, a second protein purification and biochemical characterization with optimized assay conditions was performed to confirm these results.

\subsubsection{Enzyme Activity}

Enzyme kinetic measurements with plant HRP, non-mutated benchmark rHRP and rHRP variant N13D/N57S/N255D/N268D were performed in $50 \mathrm{mM} \mathrm{KH}_{2} \mathrm{PO}_{4} \mathrm{pH} 5$ using 96-well plates. Here, N13D/N57S/N255D/N268D showed an 8-fold enhanced catalytic efficiency $\left(\mathrm{K}_{\text {cat }} / \mathrm{K}_{\mathrm{m}}\right)$ and an 8-fold increased turnover number $\left(\mathrm{k}_{\mathrm{cat}}\right)$ when compared to the benchmark enzyme (Table 5). The increase in $\mathrm{k}_{\text {cat }}$ for N13D/N57S/N255D/N268D was similar to the results obtained with the previous assay (Table 2, 10-fold). Besides, the $\mathrm{K}_{\mathrm{m}}(0.27 \mathrm{mM})$ for plant HRP was similar to values reported in literature: $0.27 \mathrm{mM}$ [35] and $0.11 \mathrm{mM}$ [34]. However, the $\mathrm{K}_{\mathrm{m}}$-values observed for plant HRP in potassium phosphate buffer differed significantly between the two assays (Tables 4 and 5). We assume that this might be due to differences in $\mathrm{pH}$, as the Michaelis Menten constant in $50 \mathrm{mM} \mathrm{KH}_{2} \mathrm{PO}_{4}$ pH 6 was $1.5 \mathrm{mM}$ (Table 4) and Gundinger et al. [17] reported $1.75 \mathrm{mM}$ in $50 \mathrm{mM} \mathrm{KH}_{2} \mathrm{PO}_{4} \mathrm{pH}_{6.5}$. Gilfoyle et al. [35] and Grigorenko et al. [34] used sodium phosphate/citrate buffer at pH 5 and sodium acetate buffer at $\mathrm{pH} 5$, respectively, which resulted in $\mathrm{K}_{\mathrm{m}}$-values of $0.27 \mathrm{mM}$ [35] and $0.11 \mathrm{mM}$ [34] which are in accordance with $0.27 \mathrm{mM}$ in potassium phosphate (Table 5).

Table 5. Kinetic characteristics of plant HRP, rHRP and N13D/N57S/N255D/N268D with ABTS as reducing substrate in $50 \mathrm{mM} \mathrm{KH}_{2} \mathrm{PO}_{4} \mathrm{pH} 5$.

\begin{tabular}{ccccc}
\hline HRP variant & $\mathbf{K}_{\mathbf{m}}[\mathbf{m M}]$ & $\mathbf{V}_{\mathbf{m a x}}\left[\mathbf{m o l}^{-\mathbf{1}} \mathbf{L}^{-\mathbf{1}} \times \mathbf{s}\right]$ & $\mathbf{K}_{\mathbf{c a t}}\left[\mathbf{s}^{-\mathbf{1}}\right]$ & $\mathbf{K}_{\mathbf{c a t}} / \mathbf{K}_{\mathbf{m}}\left[\mathbf{m} \mathbf{M}^{-\mathbf{1}} \mathbf{s}^{-\mathbf{1}}\right]$ \\
\hline Benchmark rHRP & $0.44 \pm 0.10$ & $2.0 \times 10^{-6} \pm 9.8 \times 10^{-8}$ & $2.24 \pm 0.11$ & $5.07 \pm 1.16$ \\
N13D/N57S/N255D/N268D & $0.45 \pm 0.12$ & $1.8 \times 10^{-5} \pm 1.1 \times 10^{-6}$ & $17.4 \pm 1.01$ & $39.1 \pm 10.5$ \\
HRP Type VI-A & $0.27 \pm 0.05$ & $8.8 \times 10^{-3} \pm 6.0 \times 10^{-4}$ & $422 \pm 28.9$ & $1,572 \pm 306$ \\
\hline
\end{tabular}

\subsubsection{Thermal Stability}

The thermal stability of plant HRP VI-A, non-mutated benchmark rHRP and rHRP variant N13D/N57S/N255D/N268D was determined at $60{ }^{\circ} \mathrm{C}$ (Table 6). The measurement was performed at pH 7 to guarantee comparability with the previous assay (Section 2.2.1.2). Interestingly, the half-life of all HRP species measured in $50 \mathrm{mM} \mathrm{KH}_{2} \mathrm{PO}_{4}$ buffer $\mathrm{pH} 7$ was slightly higher than the half-life in $50 \mathrm{mM}$ BisTris $/ \mathrm{HCl}$ pH 7, 7\% glycerol, $100 \mathrm{mM} \mathrm{NaCl}$ (Table 4). Asad et al. [36] and Haifeng et al. [37] found that phosphate buffers can influence the thermostability of horseradish peroxidase. Although the samples were kept in $50 \mathrm{mM}$ BisTris $/ \mathrm{HCl} \mathrm{pH}$ 7, 7\% glycerol, $100 \mathrm{mM} \mathrm{NaCl}$ during heat exposition in both experiments, it might still be possible that potassium phosphate had a stabilizing effect during the activity measurement. In both experiments the plant HRP was far more stable than the rHRP variants (Tables 3 and 6) because glycans improve enzyme stability [18]. The thermostability of the quadruple mutant N13D/N57S/N255D/N268D was 2-fold higher than the stability of the benchmark rHRP enzyme (Table 6) which is in accordance with the previous assay (Table 3; 2.4-fold).

Table 6. Half-life of plant HRP, rHRP and N13D/N57S/N255D/N268D at $60^{\circ} \mathrm{C}$ in $50 \mathrm{mM} \mathrm{KH}_{2} \mathrm{PO}_{4} \mathrm{pH} 7$.

\begin{tabular}{cc}
\hline HRP Variant & $\boldsymbol{t}_{\mathbf{1 / 2}}$ at $\mathbf{6 0}{ }^{\circ} \mathbf{C}$ \\
\hline Benchmark rHRP & $3 \min 29 \mathrm{~s} \pm 1 \mathrm{~s}$ \\
N13D/N57S/N255D/N268D & $7 \min 41 \mathrm{~s} \pm 31 \mathrm{~s}$ \\
HRP Type VI-A & $133 \min \pm 1 \min 20 \mathrm{~s}$ \\
\hline
\end{tabular}


Summarizing, the quadruple mutant showed a significantly augmented performance concerning thermal stability as well as catalytic activity with ABTS as substrate. Therefore, this variant is considered a good starting point for further enzyme engineering approaches.

\section{Materials and Methods}

\subsection{Chemicals}

Chemicals were purchased from Carl Roth (Karlsruhe, Germany) or AppliChem (Darmstadt, Germany). Plant HRP Type VI-A (Cat. No.: P6782) was purchased from Sigma-Aldrich (St. Louis, MO, USA), enzymes were purchased from New England Biolabs (Ipswich, MA, USA) or Thermo Fisher Scientific Inc. (Waltham, MA, USA), 2,2'-azino-bis(3-ethylbenzothiazoline-6-sulphonic acid) (ABTS) was purchased from Sigma-Aldrich or AMRESCO ${ }^{\circledR}$ biochemical (Solon, OH, USA).

\subsection{Strains and Plasmids}

The hrp gene coding for HRP variant C1A was codon-optimized for E. coli and obtained from GenSript USA Inc. (Piscataway, NJ, USA). HRP was produced as a His6-tagged recombinant protein from pET39b ${ }^{+}$in the E. coli strain BL21 (DE3) (Lucigen, Middleton, WI, USA). The plasmid pET39b+ (Novagen, San Diego, CA, USA) encodes a Dsb tag for export and periplasmic folding, so that a DsbA fusion protein with a HIS tag between the $d s b A$ sequence and the $h r p$ sequence is generated.

\subsection{Strain Generation by Site-Directed Mutagenesis}

The following plasmids were constructed with standard molecular cloning techniques [38]. Whole plasmid PCR was used to introduce mutations in the hrp gene by site-directed mutagenesis. The 7 $\mathrm{kb}$ fragment was amplified with the respective oligonucleotides to generate single, double, triple and quadruple mutations (Table 7). All oligonucleotides were purchased from Microsynth (Balgach, Switzerland). Each PCR reaction contained 1× Q5 Reaction Buffer, $200 \mu \mathrm{M}$ dNTP Mix, $200 \mathrm{nM}$ of both forward and reverse primer, $100 \mathrm{ng}$ template vector DNA and 1 U Q5 High-Fidelity DNA Polymerase. The PCR products were purified with the Monarch PCR \& DNA Cleanup Kit from New England Biolabs (NEB, Ipswich, MA, USA) and the template plasmid DNA was removed by FastDigest $D p n \mathrm{I}$ (Thermo Scientific ${ }^{\mathrm{TM}}$, Waltham, MA, USA) digestion. 1 FDU (FastDigest unit, see Abbreviations) of $D p n \mathrm{I}$ was added to the cleaned PCR products and incubated overnight at $37^{\circ} \mathrm{C}$. After heat inactivation at $80^{\circ} \mathrm{C}$ for $20 \mathrm{~min}$, the plasmids were transformed into BL21 (DE3). All DNA inserts of the recombinant plasmids were verified by DNA sequencing (Microsynth, Balgach, Switzerland).

Table 7. Oligonucleotide primers to mutate four Asn residues that act as N-glycosylation sites to either Asp or Ser.

\begin{tabular}{|c|c|c|}
\hline $\mathrm{N}$-site & Name & Sequence $\left(5^{\prime} \rightarrow 3^{\prime}\right.$ Direction) \\
\hline Benchmark rHRP & pET39b ${ }^{+}$hrp_fwd & GCGAATGCCCATGGATATGCAACTG \\
\hline Benchmark rHRP & pET39b ${ }^{+}$hrp_rev & CCCGGGACTCGAGTTACGAGTT \\
\hline N13 & N13D_fwd2 & CTGCCCGGATGTGAGCAACA \\
\hline N13 & N13D_rev2 & CGGGCAGCTATTATCATAGAAGG \\
\hline N57 & N57S fwd & CTGCTGGACAGCACCACGTCC \\
\hline N57 & N57S rev & GTCCAGCAGGATACTTGCATCACAGCC \\
\hline N255 & N255D_fwd2 & TTAGTTCCCCGGATGC \\
\hline N255 & N255D_rev2 & CGGGGAACTAAACAGTTCT \\
\hline N268 & N268D fwd & GTTCGTTCATTTGCCGATTCGACCCAGA \\
\hline N268 & N268D rev & GGCAAATGAACGAACCAGCGGAATCG \\
\hline
\end{tabular}

The mutated sites are underlined. fwd: forward; rev: reverse. 


\subsection{Growth Conditions and Protein Production}

LB medium (10 $\mathrm{g} \mathrm{L}^{-1}$ tryptone, $10 \mathrm{~g} \mathrm{~L}^{-1} \mathrm{NaCl}$ and $5 \mathrm{~g} \mathrm{~L}^{-1}$ yeast extract) or $\mathrm{SB}$ medium $\left(32 \mathrm{~g} \mathrm{~L}^{-1}\right.$ tryptone; $20 \mathrm{~g} \mathrm{~L}^{-1}$ yeast extract; $5 \mathrm{~g} \mathrm{~L}^{-1} \mathrm{NaCl} ; 5 \mathrm{mM} \mathrm{NaOH}$ ) was used for cultivation of BL21 (DE3) strains. Kanamycin was added to a final concentration of $50 \mathrm{mg} \mathrm{L}^{-1}$ to ensure plasmid maintenance. Pre-cultures were grown overnight at $37^{\circ} \mathrm{C}$ with shaking $\left(250 \mathrm{rpm}\right.$ ) in $50 \mathrm{~mL} \mathrm{LB}{ }^{\mathrm{Kan}}$ or SB${ }^{\mathrm{Kan}}$ medium and 2.5 L Ultra Yield Flasks (UYF) were inoculated to reach an optical density $\left(\mathrm{OD}_{600}\right)$ of 0.3 in a final volume of $500 \mathrm{~mL} \mathrm{LB}{ }^{\mathrm{Kan}}$ or $\mathrm{SB}^{\mathrm{Kan}}$ medium. The cells were grown at $37^{\circ} \mathrm{C}$ with shaking $(250 \mathrm{rpm})$ until an $\mathrm{OD}_{600}$ of 0.5 , subsequently $h r p$ expression was induced by adding $0.1 \mathrm{mM}$ isopropyl $\beta$-D-1-thiogalactopyranoside (IPTG). After growth for $20 \mathrm{~h}$ at $25^{\circ} \mathrm{C}$ and $250 \mathrm{rpm}$, the cells were harvested by centrifugation ( $4500 \mathrm{rpm}$, $\left.30 \min , 4^{\circ} \mathrm{C}\right)$.

\subsection{Protein Purification}

The cell pellets were resuspended in buffer A $(50 \mathrm{mM}$ BisTris $/ \mathrm{HCl} \mathrm{pH} 7,500 \mathrm{mM} \mathrm{NaCl}$, $40 \mathrm{mM}$ imidazole) with cOmplete ${ }^{\mathrm{TM}}$ Protease Inhibitor Cocktail (Roche, Basel, Switzerland). The cell suspension was homogenized with an Avestin Emulsiflex C3 high pressure homogenizer (Avestin, Ottawa, ON, Canada) for 10 passages at 1000 bar and centrifuged afterwards at 10,000 rpm for $1 \mathrm{~h}$. Particles were removed from the supernatant by filtration $(0.2 \mu \mathrm{m})$ prior to protein purification with IMAC using the Äkta pure system (GE Healthcare, Chicago, IL, USA). The column (HisTrap ${ }^{\text {TM }}$ Fast Flow Crude $1 \mathrm{~mL}$, GE Healthcare) was equilibrated with 10 column volumes (CV) buffer A and the crude extract was loaded with a linear flow rate of $156 \mathrm{~cm} \mathrm{~h}^{-1}$. Subsequently, the column was washed with 10-20 CV buffer A before step elution with $100 \%$ buffer B $(50 \mathrm{mM}$ BisTris $/ \mathrm{HCl} \mathrm{pH} 7,500 \mathrm{mM}$ $\mathrm{NaCl}, 500 \mathrm{mM}$ imidazole) at a linear flow rate of $156 \mathrm{~cm} \mathrm{~h}^{-1}$. The eluted protein fractions were desalted with Sephadex G-25 PD-10 desalting columns (GE Healthcare, Chicago, IL, USA) and eluted in buffer $\mathrm{C}(50 \mathrm{mM}$ BisTris/ $\mathrm{HCl} \mathrm{pH} \mathrm{7,7 \%} \mathrm{glycerol,} 100 \mathrm{mM} \mathrm{NaCl})$. Glycerol and sodium chloride were added to the buffer as these substances were found to positively impact on rHRP stability (data not shown). Total protein content was measured using the Bradford assay [39] and the eluate was analysed by SDS PAGE. The concentration of rHRP was calculated as $\mu \mathrm{M} \mathrm{mL}^{-1}$ using $61.5 \mathrm{kDa}$ (with DsbA Protein and His tag) as molecular mass of the fusion protein. Hemin and calcium chloride were added in a 2-fold and 4-fold molar amount, respectively and the enzyme preparations were incubated over night at $4{ }^{\circ} \mathrm{C}$ with slight agitation.

\subsection{SDS PAGE}

SDS PAGE was performed according to the Laemmli protocol [40]. Mini-PROTEAN ${ }^{\circledR}$ TGX Stain-Free $^{\text {TM }}$ Precast Gels (Bio-Rad, Hercules, CA, USA) were used and the gel was run with SDS running buffer ( $25 \mathrm{mM}$ Tris, $200 \mathrm{mM}$ glycine, $0.1 \%$ SDS) in a Bio-Rad Mini-PROTEAN ${ }^{\circledR}$ Tetra Cell. Proteins were separated at $125 \mathrm{~V}$ for $1 \mathrm{~h}$ and the bands were visualized with Coomassie Brilliant Blue solution. Bio-Rad Precision Plus Protein ${ }^{\mathrm{TM}}$ Dual Xtra Prestained Protein Standard or Thermo Scientific PageRuler ${ }^{\text {TM }}$ Plus Prestained Protein Ladder, 10 to $250 \mathrm{kDa}$ (Waltham, MA, USA) were used as mass standards. The SDS PAGE was analysed using a ChemiDoc ${ }^{\mathrm{TM}}$ MP System with Image Lab $^{\mathrm{TM}}$ Software (Bio-Rad, Hercules, CA, USA).

\subsection{Biochemical Enzyme Characterization}

\subsubsection{Assay Development}

\subsubsection{Pathlength Correction for Microplates}

The pathlength for $200 \mu \mathrm{L}$ reaction volume was determined experimentally by measuring the absorbance of MilliQ water in the Tecan Infinite M200 PRO (Tecan, Männedorf, Switzerland) and the Hitachi U-2900 spectrophotometer (Hitachi, Tokyo, Japan). Water absorption can be measured at near infrared wavelength with a maximum absorbance at $975 \mathrm{~nm}$, the measurement at $900 \mathrm{~nm}$ subtracts 
background absorbance (e.g., plastic of 96-well plate). The correct pathlength for the 96-well plates was then calculated according to Equation (1):

$$
\text { pathlength }=\frac{A 975 \mathrm{~nm}(\text { well })-A 900 \mathrm{~nm}(\text { well })}{A 975 \mathrm{~nm}(\text { cuvette })-A 900 \mathrm{~nm}(\text { cuvette })} \times 10 \mathrm{~mm}
$$

Thus, a reaction volume of $200 \mu \mathrm{L}$ results in a pathlength of $0.58 \mathrm{~cm}$ in 96-well plates.

\subsubsection{Determination of Extinction Coefficient for ABTS}

The extinction coefficient of the ABTS radical was determined experimentally with a Tecan Infinite M200 PRO system (Tecan, Männedorf, Switzerland) for ABTS purchased from Sigma-Aldrich (St. Louis, $\mathrm{MO}, \mathrm{USA}$ ) and AMRESCO ${ }^{\circledR}$ biochemical (Solon, OH, USA). ABTS concentrations ranging from $0 \mathrm{mM}$ to $0.15 \mathrm{mM}$ were measured in $50 \mathrm{mM} \mathrm{KH}_{2} \mathrm{PO}_{4} \mathrm{pH} 5$ buffer with $1 \mathrm{mM}$ hydrogen peroxide in a final volume of $200 \mu \mathrm{L}$ and $22.5 \mathrm{ng}$ plant HRP Type VI-A (Sigma-Aldrich, Cat. No.: P6782). The reaction was followed to the plateau phase in a 96-well plate at $420 \mathrm{~nm}$ for $40 \mathrm{~min}$ at $30^{\circ} \mathrm{C}$. Finally, the extinction coefficient was calculated from the slope of the linear regression line of ABTS concentration plotted against maximal absorbance. The extinction coefficient of ABTS at $420 \mathrm{~nm}$ is $27 \mathrm{mM}^{-1} \mathrm{~cm}^{-1}$ for ABTS purchased from both companies (Sigma-Aldrich: $y=15.455 x+0.0548 ; R^{2}=0.9977 /$ AMRESCO $^{\circledR}$ biochemical: $\mathrm{y}=15.455 \mathrm{x}+0.0314 ; \mathrm{R}^{2}=0.9986$ ).

\subsubsection{Enzyme Activity Calculation}

HRP activity in Units $\mathrm{mL}^{-1}$ (1 Unit is defined as the amount of enzyme which oxidizes $1 \mu \mathrm{mol}$ of ABTS per minute) was calculated according to Equation (2):

$$
\frac{U}{\mathrm{~mL}}=\frac{(\Delta A 420 \mathrm{~nm}-\Delta A 420 \mathrm{~nm} \text { blank }) \times \text { total volume of reaction } \times d}{\varepsilon \times \mathrm{p} \times \text { sample volume }}
$$

$d=$ dilution factor

$\mathrm{p}=$ pathlength in $\mathrm{cm}$, which is 1 for cuvettes and 0.58 in a 96-well plate when the reaction volume is $200 \mu \mathrm{L}$ (see Section 3.7.1.1).

$\varepsilon=27 \mathrm{mM}^{-1} \mathrm{~cm}^{-1}$

\subsubsection{Catalytic Activity of Plant HRP under Different Conditions}

Enzyme activity of plant HRP Type VI-A (Sigma-Aldrich, Cat. No.: P6782, St. Louis, MO, USA)

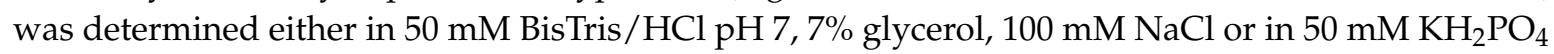
$\mathrm{pH}$ 6. The reaction mixture in the cuvette contained $27.6 \mathrm{ng} \mathrm{HRP}$, a saturating hydrogen peroxide concentration of $1 \mathrm{mM}$ and varying ABTS concentrations $(0.1-10 \mathrm{mM})$ in $50 \mathrm{mM}$ BisTris/ $\mathrm{HCl} \mathrm{pH}$ $7,7 \%$ glycerol, $100 \mathrm{mM} \mathrm{NaCl}$ or in $50 \mathrm{mM} \mathrm{KH}_{2} \mathrm{PO}_{4} \mathrm{pH} 6$ with a final volume of $1 \mathrm{~mL}$. The increase in absorption was followed at $420 \mathrm{~nm}$ for $180 \mathrm{~s}$ at $30{ }^{\circ} \mathrm{C}$ in a Hitachi U-2900 spectrophotometer (Hitachi, Tokyo, Japan). All measurements were performed in triplicates. Kinetic parameters were calculated using OriginPro software (OriginLab Corporation 2016, Northampton, MA, USA). As these measurements revealed substantial differences concerning the kinetic parameters between the two buffers, it was decided to further investigate the influence of buffer substance, $\mathrm{pH}$ and buffer additives in a 96-well plate format. Here, the reaction mixture in each well contained a saturating hydrogen peroxide concentration of $1 \mathrm{mM}$ and $5 \mathrm{mM}$ ABTS in a final volume of $200 \mu \mathrm{L}$. Commercially available plant HRP (9 ng; Sigma-Aldrich, Cat. No.: P6782, St. Louis, MO, USA) was added to the reaction mixture and the increase in absorption was followed at $420 \mathrm{~nm}$ for $180 \mathrm{~s}$ at $30^{\circ} \mathrm{C}$ in a Tecan Infinite M200 PRO instrument (Tecan, Männedorf, Switzerland). The following buffers were used: $50 \mathrm{mM}$ $\mathrm{KH}_{2} \mathrm{PO}_{4} \mathrm{pH} 5 ; 50 \mathrm{mM} \mathrm{KH}_{2} \mathrm{PO}_{4} \mathrm{pH}$ 6.5; $50 \mathrm{mM} \mathrm{KH}_{2} \mathrm{PO}_{4} \mathrm{pH}$ 7; $50 \mathrm{mM}$ BisTris/ $\mathrm{HCl} \mathrm{pH}$ 7, 7\% glycerol, $100 \mathrm{mM} \mathrm{NaCl}$ or $50 \mathrm{mM}$ BisTris/ $\mathrm{HCl} \mathrm{pH}$ 7. All measurements were performed in duplicates. 


\subsubsection{Enzyme Kinetics}

Enzyme kinetic parameters for the substrate ABTS were determined with non-mutated rHRP benchmark enzyme, seven rHRP mutants and commercially available plant HRP Type VI-A. The samples were either measured in cuvettes with a U-2900 spectrophotometer (Hitachi, Tokyo, Japan) or in 96-well plates using a Tecan Infinite M200 PRO instrument (Tecan, Männedorf, Switzerland).

\subsubsection{Hitachi U-2900 Spectrophotometer}

The reaction mixture in the cuvette contained $20 \mu \mathrm{L}$ protein sample, a saturating hydrogen peroxide concentration of $1 \mathrm{mM}$ and varying ABTS concentrations $(0.1-10 \mathrm{mM})$ in $50 \mathrm{mM}$ BisTris $/ \mathrm{HCl}$ $\mathrm{pH} 7,7 \%$ glycerol, $100 \mathrm{mM} \mathrm{NaCl}$ buffer with a final volume of $1 \mathrm{~mL}$. The increase in absorption was followed at $420 \mathrm{~nm}$ for $180 \mathrm{~s}$ at $30^{\circ} \mathrm{C}$ in a Hitachi U-2900 spectrophotometer. All measurements were performed in triplicates. The kinetic parameters were calculated using OriginPro software (OriginLab Corporation 2016, Northampton, MA, USA).

\subsubsection{Tecan Infinite M200 PRO}

The reaction mixture in each well of the 96-well plate contained a saturating hydrogen peroxide concentration of $1 \mathrm{mM}$ and varying ABTS concentrations $(0.1-10 \mathrm{mM})$ in $50 \mathrm{mM} \mathrm{KH}_{2} \mathrm{PO}_{4} \mathrm{pH} 5$ buffer in a final volume of $200 \mu \mathrm{L}$. Protein sample $(5 \mu \mathrm{L})$ was added to each well and was filled up with $195 \mu \mathrm{L}$ reaction mixture. The increase in absorption was followed in a 96-well plate at $420 \mathrm{~nm}$ for $180 \mathrm{~s}$ at $30^{\circ} \mathrm{C}$ in a Tecan Infinite M200 PRO instrument. Eight replicates were used for all measurements. The kinetic parameters were calculated using OriginPro software (OriginLab Corporation 2016, Northampton, MA, USA).

\subsubsection{Thermal Stability}

The thermal stability of the enzyme was assessed at $60{ }^{\circ} \mathrm{C}$ in $50 \mathrm{mM}$ BisTris/ $\mathrm{HCl} \mathrm{pH} \mathrm{7,7 \%}$ glycerol, $100 \mathrm{mM} \mathrm{NaCl}$ and the residual activity with ABTS was measured after 0, 1, 2, 3 and $5 \mathrm{~min}$ for the non-mutated rHRP benchmark enzyme and the seven rHRP mutants. The residual activity of plant HRP Type VI-A (Sigma-Aldrich, Cat. No.: P6782, St. Louis, MO, USA) was measured after 0, 30, 60, 90 and $120 \mathrm{~min}$, respectively. The protein concentration was normalized to $0.05 \mathrm{~g} \mathrm{~L}^{-1}$ for all samples to minimize potential influences of protein concentrations on thermal stability. The reaction mixture contained $20 \mu \mathrm{L}$ of protein, a saturating hydrogen peroxide concentration of $1 \mathrm{mM}$ and $10 \mathrm{mM}$ ABTS in $50 \mathrm{mM}$ BisTris/ $\mathrm{HCl} \mathrm{pH} 7,7 \%$ glycerol, $100 \mathrm{mM} \mathrm{NaCl}$ or in $50 \mathrm{mM} \mathrm{KH}_{2} \mathrm{PO}_{4} \mathrm{pH} 7$ with a final volume of $1 \mathrm{~mL}$. The increase in absorption was followed at $420 \mathrm{~nm}$ for $180 \mathrm{~s}$ at $30{ }^{\circ} \mathrm{C}$ in a Hitachi U-2900 spectrophotometer (Hitachi, Tokyo, Japan). The residual enzyme activity was plotted against incubation time and the half-life at $60^{\circ} \mathrm{C}$ was calculated using the rate of inactivation in Equation (3):

$$
t_{1 / 2}=\frac{\ln 2}{k_{\text {in }}}
$$

$t_{1 / 2}=$ half life

$k_{\text {in }}=$ slope of the logarithmic residual activity

\section{Conclusions}

HRP has many features that make it suitable for therapeutic use: it is stable at $37^{\circ} \mathrm{C}$, shows high activity at physiological $\mathrm{pH}$ and can be conjugated to antibodies or lectins [9]. Thus, it is highly interesting to engineer rHRP for increased activity and stability for use in medical applications. In our study we discovered a new non-glycosylated rHRP variant with improved characteristics by site-directed mutagenesis of amino acids at the N-glycosylation sites. N13D/N57S/N255D/N268D was found to substantially increase activity with ABTS as substrate, the catalytic efficiency of this variant was 8-fold higher when compared to the rHRP benchmark enzyme. Moreover, N13D/N57S/N255D/N268D is 
2-fold more stable towards high temperature exposure than the non-mutated rHRP. Currently, we work on further improvement of N13D/N57S/N255D/N268D by directed evolution, as well as the additional introduction of selected mutants (see Table 1). Finally, our future goal will be to produce the resulting non-glycosylated rHRP variant in a large-scale inclusion body process.

Supplementary Materials: Supplementary materials can be found at http:/ /www.mdpi.com/1422-0067/20/4/ 916/s1.

Author Contributions: Conceptualization, O.S.; Methodology, O.S. and D.H.; Validation, O.S. and D.H.; Formal analysis, D.H.; Investigation, D.H.; Resources, O.S.; Data curation, D.H.; Writing—original draft preparation, D.H.; Writing-review and editing, O.S. and D.H.; Visualization, D.H.; Supervision, O.S.; Project administration, O.S.; Funding acquisition, O.S.

Funding: This research was funded by Open Access Funding by the Austrian Science Fund (FWF), grant number P30872-B26.

Conflicts of Interest: The authors declare no conflict of interest.

\section{Abbreviations}

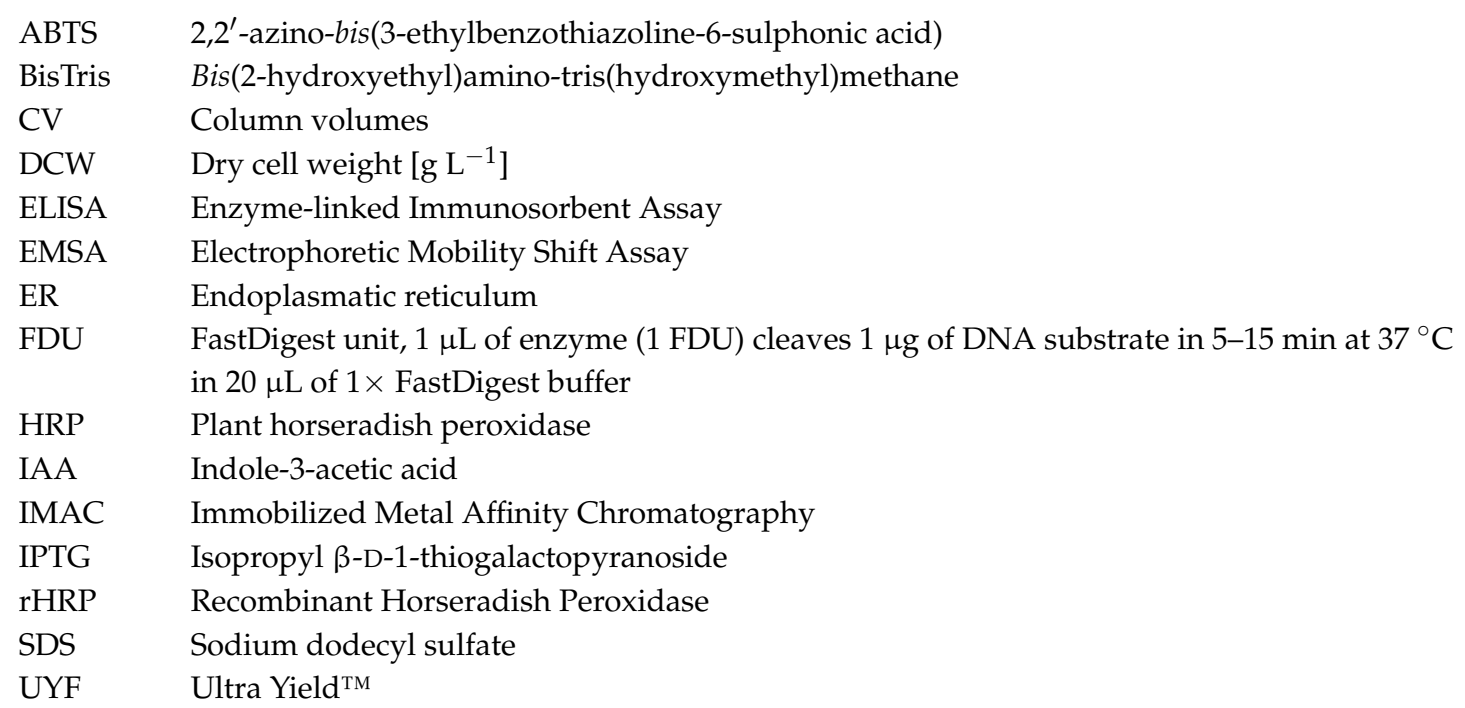

\section{References}

1. Gholami-Borujeni, F.; Mahvi, A.H.; Naseri, S.; Faramarzi, M.A.; Nabizadeh, R.; Alimohammadi, M. Application of immobilized horseradish peroxidase for removal and detoxification of azo dye from aqueous solution. Res. J. Chem. Environ. 2011, 15, 217-222.

2. Krieg, R.; Halbhuber, K. Recent advances in catalytic peroxidase histochemistry. Cell. Mol. Biol. (Noisy-le-Grand) 2003, 49, 547-563.

3. Litescu, S.C.; Eremia, S.; Radu, G.L. Biosensors for the determination of phenolic metabolites. In Bio-Farms for Nutraceuticals; Springer: Boston, MA, USA, 2010; pp. 234-240. [CrossRef]

4. Marquette, C.A.; Blum, L.J. Chemiluminescent enzyme immunoassays: A review of bioanalytical applications. Bioanalysis 2009, 1, 1259-1269. [CrossRef] [PubMed]

5. Ryan, B.J.; Carolan, N.; O'Fagain, C. Horseradish and soybean peroxidases: Comparable tools for alternative niches? Trends Biotechnol. 2006, 24, 355-363. [CrossRef] [PubMed]

6. Vasileva, N.; Godjevargova, T.; Ivanova, D.; Gabrovska, K. Application of immobilized horseradish peroxidase onto modified acrylonitrile copolymer membrane in removing of phenol from water. Int. J. Biol. Macromol. 2009, 44, 190-194. [CrossRef] [PubMed]

7. Yang, H. Enzyme-based ultrasensitive electrochemical biosensors. Curr. Opin. Chem. Biol. 2012, 16, $422-428$. [CrossRef] [PubMed]

8. Welinder, K.G. Covalent structure of the glycoprotein horseradish peroxidase (EC 1.11. 1.7). FEBS Lett. 1976, 72, 19-23. [CrossRef] 
9. Veitch, N.C. Horseradish peroxidase: A modern view of a classic enzyme. Phytochemistry 2004, 65, 249-259. [CrossRef] [PubMed]

10. Huddy, S.M.; Hitzeroth, I.I.; Meyers, A.E.; Weber, B.; Rybicki, E.P. Transient Expression and Purification of Horseradish Peroxidase C in Nicotiana benthamiana. Int. J. Mol. Sci. 2018, 19, 115. [CrossRef] [PubMed]

11. Matsui, T.; Tabayashi, A.; Iwano, M.; Shinmyo, A.; Kato, K.; Nakayama, H. Activity of the C-terminal-dependent vacuolar sorting signal of horseradish peroxidase C1a is enhanced by its secondary structure. Plant Cell Physiol. 2011, 52, 413-420. [CrossRef]

12. Matsui, T.; Nakayama, H.; Yoshida, K.; Shinmyo, A. Vesicular transport route of horseradish C1a peroxidase is regulated by $\mathrm{N}$-and C-terminal propeptides in tobacco cells. Appl. Microbiol. Biotechnol. 2003, 62, 517-522. [CrossRef] [PubMed]

13. Wuhrer, M.; Hokke, C.H.; Deelder, A.M. Glycopeptide analysis by matrix-assisted laser desorption/ionization tandem time-of-flight mass spectrometry reveals novel features of horseradish peroxidase glycosylation. Rapid Commun. Mass Spectrom. 2004, 18, 1741-1748. [CrossRef] [PubMed]

14. Wuhrer, M.; Balog, C.I.; Koeleman, C.A.; Deelder, A.M.; Hokke, C.H. New features of site-specific horseradish peroxidase (HRP) glycosylation uncovered by nano-LC-MS with repeated ion-isolation/fragmentation cycles. Biochim. Biophys. Acta (BBA)-Gen. Subj. 2005, 1723, 229-239. [CrossRef] [PubMed]

15. Krainer, F.W.; Glieder, A. An updated view on horseradish peroxidases: Recombinant production and biotechnological applications. Appl. Microbiol. Biotechnol. 2015, 99, 1611-1625. [CrossRef] [PubMed]

16. Smith, A.T.; Santama, N.; Dacey, S.; Edwards, M.; Bray, R.C.; Thorneley, R.; Burke, J.F. Expression of a synthetic gene for horseradish peroxidase $\mathrm{C}$ in Escherichia coli and folding and activation of the recombinant enzyme with $\mathrm{Ca}^{2+}$ and heme. J. Biol. Chem. 1990, 265, 13335-13343. [PubMed]

17. Gundinger, T.; Spadiut, O. A comparative approach to recombinantly produce the plant enzyme horseradish peroxidase in Escherichia coli. J. Biotechnol. 2017, 248, 15-24. [CrossRef] [PubMed]

18. Asad, S.; Khajeh, K.; Ghaemi, N. Investigating the structural and functional effects of mutating Asn glycosylation sites of horseradish peroxidase to Asp. Appl. Biochem. Biotechnol. 2011, 164, 454-463. [CrossRef]

19. Capone, S.; Pletzenauer, R.; Maresch, D.; Metzger, K.; Altmann, F.; Herwig, C.; Spadiut, O. Glyco-variant library of the versatile enzyme horseradish peroxidase. Glycobiology 2014, 24, 852-863. [CrossRef]

20. Asad, S.; Dastgheib, S.M.; Khajeh, K. Construction of a horseradish peroxidase resistant toward hydrogen peroxide by saturation mutagenesis. Biotechnol. Appl. Biochem. 2016, 63, 789-794. [CrossRef]

21. Lin, Z.; Thorsen, T.; Arnold, F.H. Functional expression of horseradish peroxidase in E. coli by directed evolution. Biotechnol. Prog. 1999, 15, 467-471. [CrossRef]

22. Ryan, B.J.; Ó'Fágáin, C. Effects of mutations in the helix G region of horseradish peroxidase. Biochimie 2008, 90, 1414-1421. [CrossRef] [PubMed]

23. Ryan, B.J.; Ó'Fágáin, C. Effects of single mutations on the stability of horseradish peroxidase to hydrogen peroxide. Biochimie 2007, 89, 1029-1032. [CrossRef] [PubMed]

24. Ryan, B.J.; O'Connell, M.J.; Ó’Fágáin, C. Consensus mutagenesis reveals that non-helical regions influence thermal stability of horseradish peroxidase. Biochimie 2008, 90, 1389-1396. [CrossRef] [PubMed]

25. Ryan, B.J.; Ó'Fágáin, C. Arginine-to-lysine substitutions influence recombinant horseradish peroxidase stability and immobilisation effectiveness. BMC Biotechnol. 2007, 7, 86. [CrossRef] [PubMed]

26. Morawski, B.; Quan, S.; Arnold, F.H. Functional expression and stabilization of horseradish peroxidase by directed evolution in Saccharomyces cerevisiae. Biotechnol. Bioeng. 2001, 76, 99-107. [CrossRef] [PubMed]

27. Morawski, B.; Lin, Z.; Cirino, P.; Joo, H.; Bandara, G.; Arnold, F.H. Functional expression of horseradish peroxidase in Saccharomyces cerevisiae and Pichia pastoris. Protein Eng. 2000, 13, 377-384. [CrossRef] [PubMed]

28. Brooks, S.A. Appropriate glycosylation of recombinant proteins for human use. Mol. Biotechnol. 2004, 28, 241-255. [CrossRef]

29. Tupper, J.; Tozer, G.M.; Dachs, G.U. Use of horseradish peroxidase for gene-directed enzyme prodrug therapy with paracetamol. Br. J. Cancer 2004, 90, 1858-1862. [CrossRef]

30. Dai, M.; Liu, J.; Chen, D.E.; Rao, Y.; Tang, Z.J.; Ho, W.Z.; Dong, C.Y. Tumor-targeted gene therapy using Adv-AFP-HRPC/IAA prodrug system suppresses growth of hepatoma xenografted in mice. Cancer Gene Ther. 2012, 19, 77-83. [CrossRef]

31. Folkes, L.; Candeias, L.; Wardman, P. Toward targeted "oxidation therapy" of cancer: Peroxidase-catalysed cytotoxicity of indole-3-acetic acids. Int. J. Radiat. Oncol. Biol. Phys. 1998, 42, 917-920. [CrossRef] 
32. Folkes, L.K.; Wardman, P. Oxidative activation of indole-3-acetic acids to cytotoxic species-A potential new role for plant auxins in cancer therapy. Biochem. Pharmacol. 2001, 61, 129-136. [CrossRef]

33. Schindelin, J.; Arganda-Carreras, I.; Frise, E.; Kaynig, V.; Longair, M.; Pietzsch, T.; Preibisch, S.; Rueden, C.; Saalfeld, S.; Schmid, B. Fiji: An open-source platform for biological-image analysis. Nat. Methods 2012, 9, 676-682. [CrossRef] [PubMed]

34. Grigorenko, V.; Chubar, T.; Kapeliuch, Y.; Börchers, T.; Spener, F.; Egorova, A. New approaches for functional expression of recombinant horseradish peroxidase C in Escherichia coli. Biocatal. Biotransform. 1999, 17, 359-379. [CrossRef]

35. Gilfoyle, D.J.; Rodriguez-Lopez, J.N.; Smith, A.T. Probing the aromatic-donor-binding site of horseradish peroxidase using site-directed mutagenesis and the suicide substrate phenylhydrazine. Eur. J. Biochem. 1996, 236, 714-722. [CrossRef] [PubMed]

36. Asad, S.; Torabi, S.-F.; Fathi-Roudsari, M.; Ghaemi, N.; Khajeh, K. Phosphate buffer effects on thermal stability and $\mathrm{H}_{2} \mathrm{O}_{2}$-resistance of horseradish peroxidase. Int. J. Biol. Macromol. 2011, 48, 566-570. [CrossRef] [PubMed]

37. Haifeng, L.; Yuwen, L.; Xiaomin, C.; Zhiyong, W.; Cunxin, W. Effects of sodium phosphate buffer on horseradish peroxidase thermal stability. J. Therm. Anal. Calorim. 2008, 93, 569-574. [CrossRef]

38. Sambrook, J.; Fritsch, E.F.; Maniatis, T. Molecular Cloning: A Laboratory Manual; Cold Spring Harbor Laboratory Press: Cold Spring Harbor, NY, USA, 1989.

39. Bradford, M.M. A rapid and sensitive method for the quantitation of microgram quantities of protein utilizing the principle of protein-dye binding. Anal. Biochem. 1976, 72, 248-254. [CrossRef]

40. Laemmli, U.K. Cleavage of structural proteins during the assembly of the head of bacteriophage T4. Nature 1970, 227, 680-685. [CrossRef]

(C) 2019 by the authors. Licensee MDPI, Basel, Switzerland. This article is an open access article distributed under the terms and conditions of the Creative Commons Attribution (CC BY) license (http:/ / creativecommons.org/licenses/by/4.0/). 